Proc. Estonian Acad. Sci. Geol., 2005, 54, 1, 5-25

\title{
Chronological data from Estonian Pleistocene
}

\author{
Volli Kalm \\ Institute of Geology, University of Tartu, Vanemuise 46, 51014 Tartu, Estonia; volli.kalm@ut.ee \\ Received 31 January 2005, in revised form 3 February 2005

\begin{abstract}
Pleistocene chronostratigraphy in Estonia is based on 60 radiocarbon $\left({ }^{14} \mathrm{C},{ }^{14} \mathrm{C}\right.$ AMS $)$, $63 \mathrm{TL} / \mathrm{OSL}$, and $17{ }^{10} \mathrm{Be}$ datings from 57 studied sites/sections that cover a time span from approximately $200000 \mathrm{yr}$ BP to the Pleistocene-Holocene chronostratigraphic boundary. For the first time all scattered data from 40 years of chronological study into Estonian Pleistocene are presented together and critically analysed in regard to validity of obtained ages. Half of the relatively abundant but scattered chronological data cover only the youngest 5000-6000 year part of the Late Weichselian. New OSL datings, together with the results of earlier palynological, carpological, and diatom studies, have invalidated almost one-third of the available ${ }^{14} \mathrm{C}$ dates, obtained mostly in the late $1960 \mathrm{~s}$ and $1970 \mathrm{~s}$. Thermoluminescence ages from tills, available from the early 1980s, are very inconsistent within the studied sections and are considered to be unreliable because of questionable bleaching of the TL signal. The results of the ${ }^{10} \mathrm{Be}$ method, recently applied to the study of deglaciation chronology of the Estonian territory, do not contradict the earlier age estimations. However, due to relatively large uncertainties of the method, the results were not able to refine the existing Late-Glacial chronology in Estonia.
\end{abstract}

Key words: geochronology, Late Weichselian, deglaciation, Estonia, dating methods.

\section{INTRODUCTION}

The first attempt to date directly the ice-marginal formations and to correlate them with adjacent regions was undertaken by Serebryannyj \& Raukas (1966). All subsequent published summaries of Pleistocene stratigraphy in Estonia (Kajak et al. 1976; Liivrand 1991; Raukas \& Gaigalas 1993; Raukas \& Kajak 1995; Pirrus \& Raukas 1996; Raukas 1998) were based on correlations of biostratigraphic (palynological) data and the superposition of till beds to other analysed and dated sections in the region. The commonly accepted model designates at least five till beds macroscopically distinguishable in glacial accumulative heights and buried bedrock valleys, occasionally separated from each other by Karuküla (Holsteinian) and Prangli (Eemian) interglacial deposits or interstadial beds (Liivrand 1991; Raukas \& Kajak 1995, 1997). The two youngest till beds are attributed to Weichselian glaciations (Raukas et al. 2004), whereas the uppermost till likely includes Late-Glacial interstadial organic-containing beds in a few places. Often the obtained dates have been rejected as unsuitable for the model supported by the authors. The aim of this paper is, firstly, to present a systematic 
and detailed review of relatively numerous chronostratigraphic data from Estonian Pleistocene and, secondly, to give a critical evaluation of the existing abundant (albeit scattered) chronological data, while presenting new information on the age of the Rõngu (Eemian) and Kõrveküla (Holsteinian) sections and an assessment of the earlier ${ }^{14} \mathrm{C}$ datings from the sections.

\section{MATERIAL AND TERMINOLOGY}

Mainly dates older than the Pleistocene-Holocene boundary at 10000 uncalibrated ${ }^{14} \mathrm{C}$ years BP (Harland et al. 1982) were incorporated into the analysis. Only few younger dates provided by Raukas (2004) were included in the database because they were obtained from obviously Pleistocene-age objects - glacial erratics. At this moment from Estonian Pleistocene 60 radiocarbon $\left({ }^{14} \mathrm{C},{ }^{14} \mathrm{C}\right.$ AMS $)$, 63 luminescence (TL, OSL), and 17 cosmogenic ${ }^{10} \mathrm{Be}$ datings are available from 57 studied sites/sections (Fig. 1), which span approximately 200000 years (Table 1).

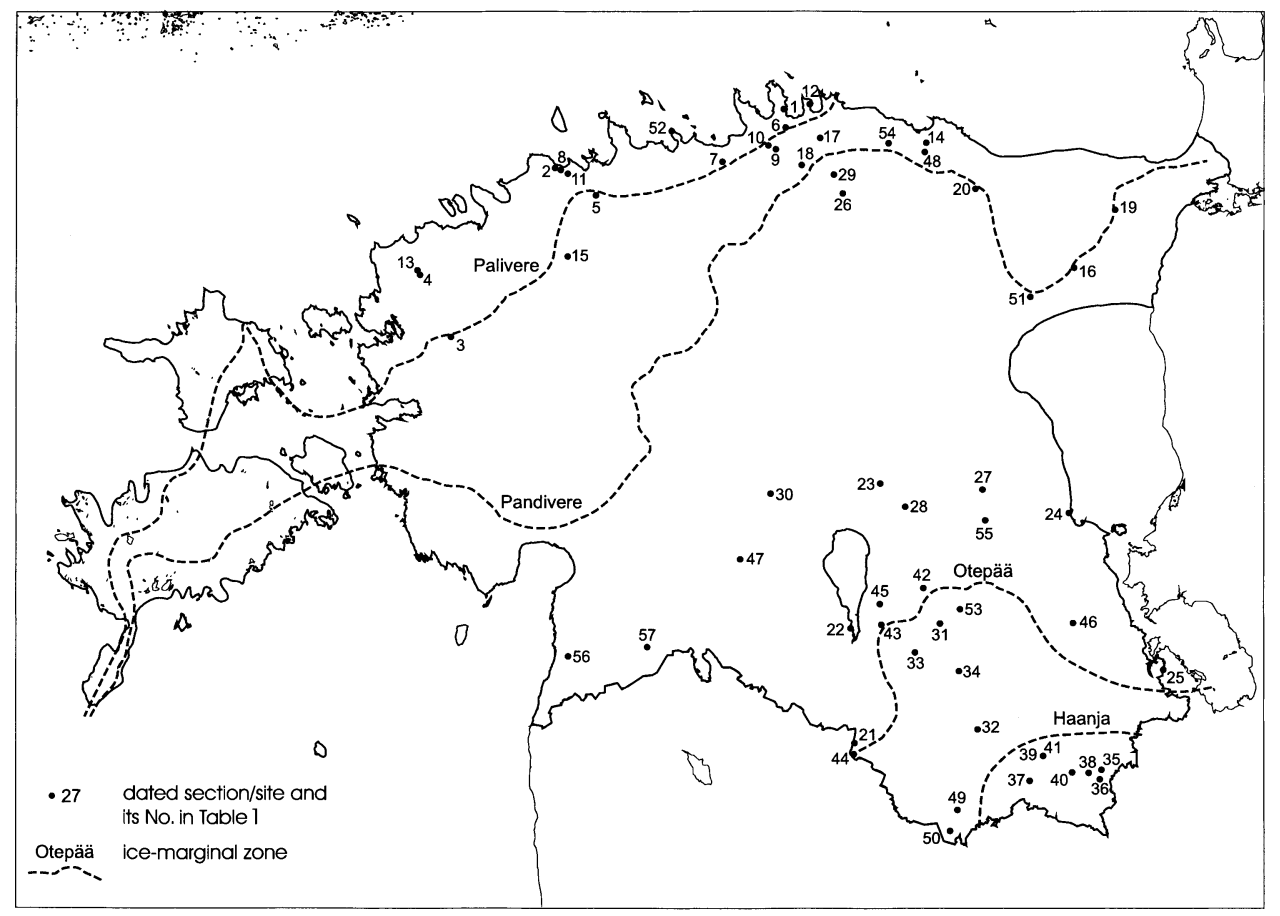

Fig. 1. Major Late-Glacial ice-marginal formations and location of dated Pleistocene sections/sites in Estonia: 1, Kasispea; 2, Tabasalu 3; 3, Palivere; 4, Nõva 1; 5, Männiku; 6, Sillaotsa; 7, Kuusalu; 8, Tabasalu 2; 9, Valgejõe; 10, Kemba; 11, Tabasalu 1; 12, Käsmu; 13, Nõva 2; 14, Kunda; 15, Vaharu; 16, Iisaku; 17, Palmse; 18, Pikasaare; 19, Pannjärve; 20, Uljaste; 21, Taimeaia (Valga); 22, Naritsa; 23, Puurmani; 24, Saviku; 25, Kuliska; 26, Kallukse; 27, Vedu; 28, Laeva; 29, Loobu; 30, Tääksi; 31, Nõuni; 32, Kurenurme; 33, Äidu; 34, Kaagvere; 35, Remmeski; 36, Viitka; 37, Viitina; 38, Pütsepa; 39, Jaanimäe 1; 40, Petruse; 41, Jaanimäe 2; 42, Peedu; 43, Rõngu; 44, Valga; 45, Valguta; 46, Mooste; 47, Heimtali; 48, Lammasmägi; 49, Kallaste; 50, Tahkumägi; 51, Tudulinna; 52, Ihasalu; 53, Kammeri; 54, Pehka; 55, Kõrveküla; 56, Arumetsa; 57, Karuküla. 


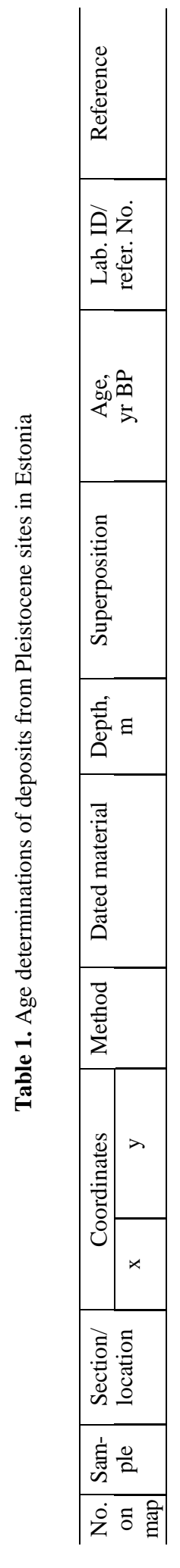

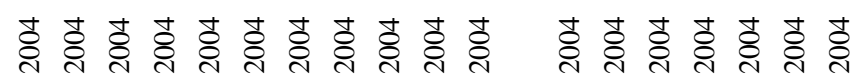

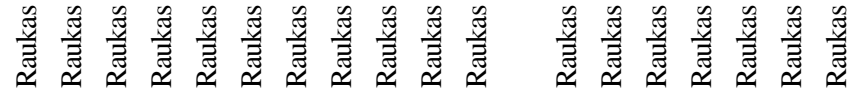

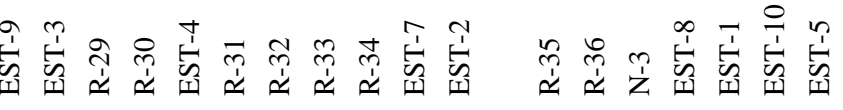

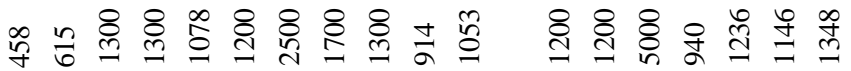

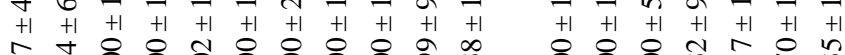

है

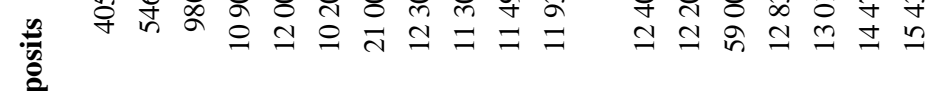

$\bar{\square}$

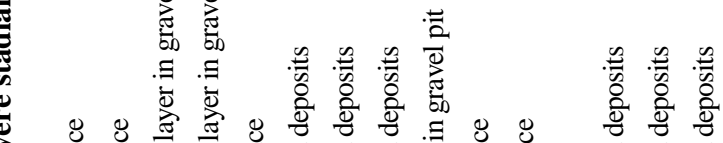

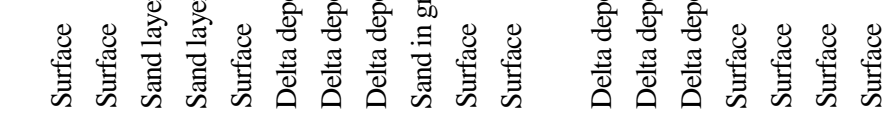

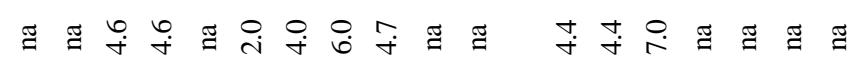

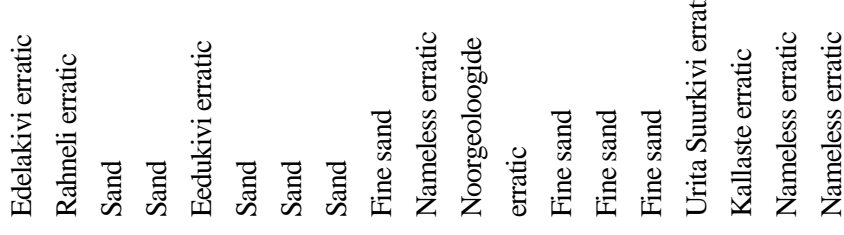

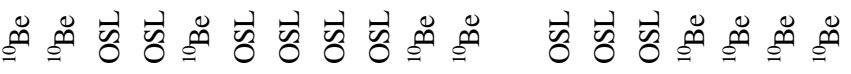

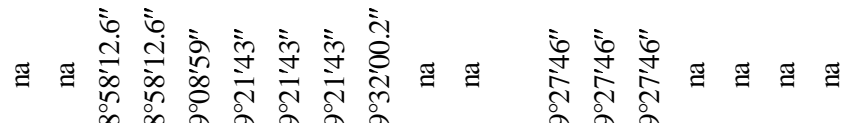
in $\infty$ in

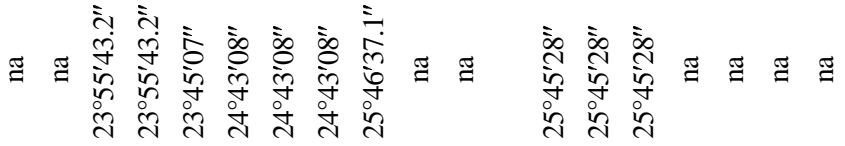

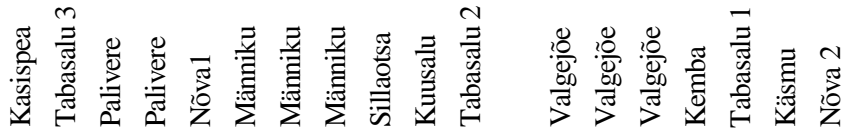

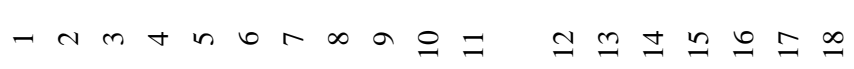

$m+n \quad 0 \wedge \infty \quad a \quad 0=\simeq$ 


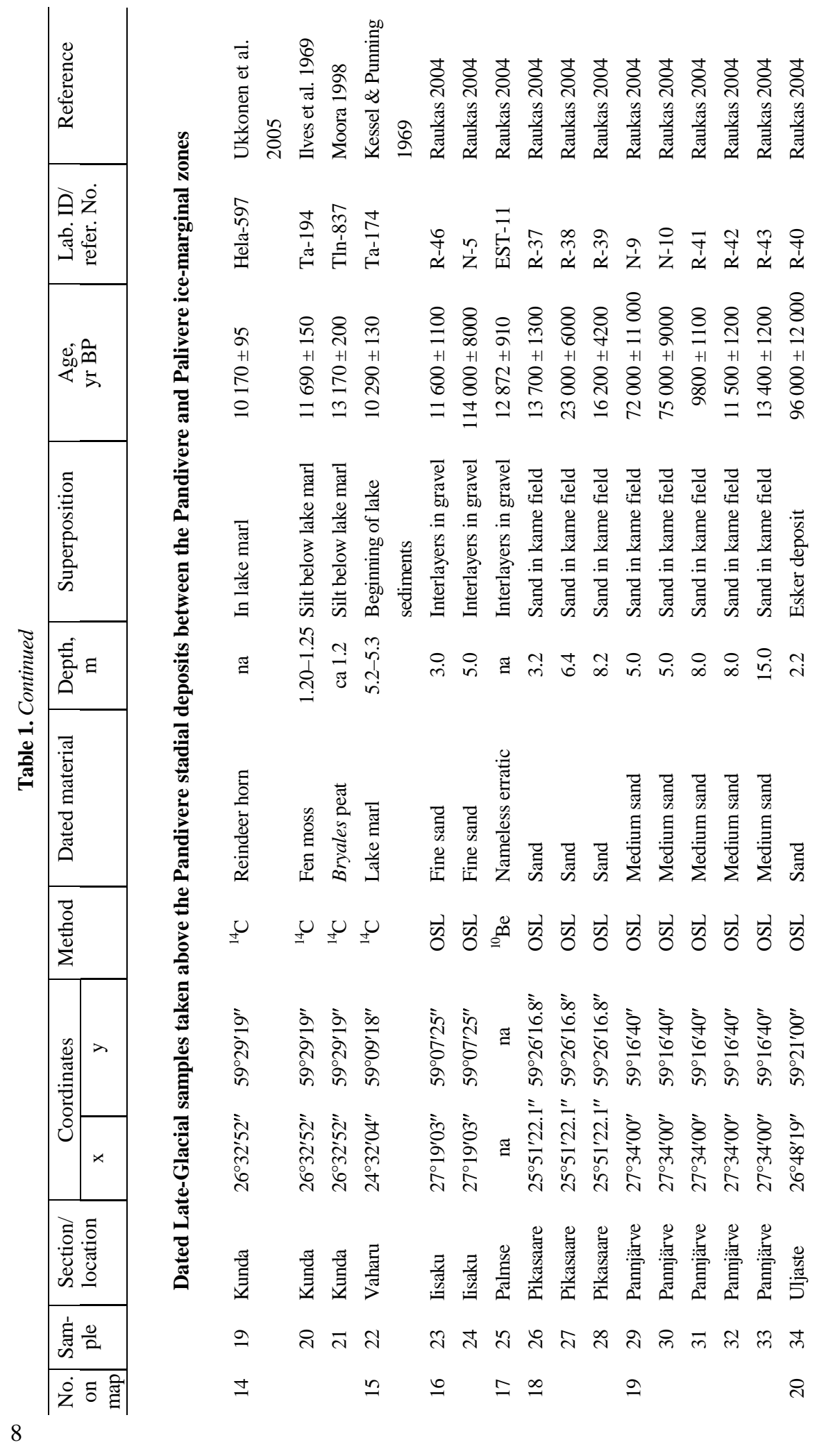




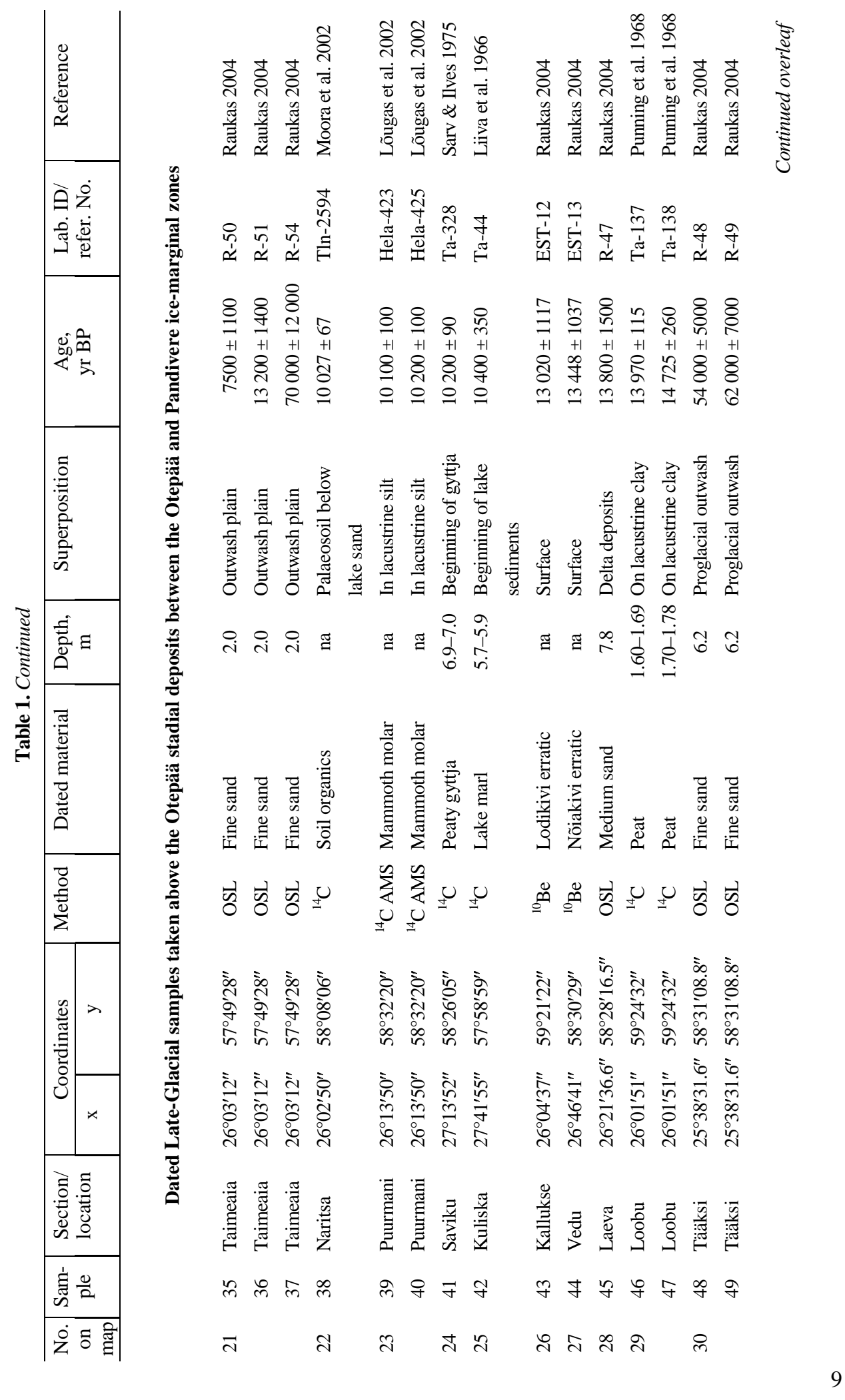




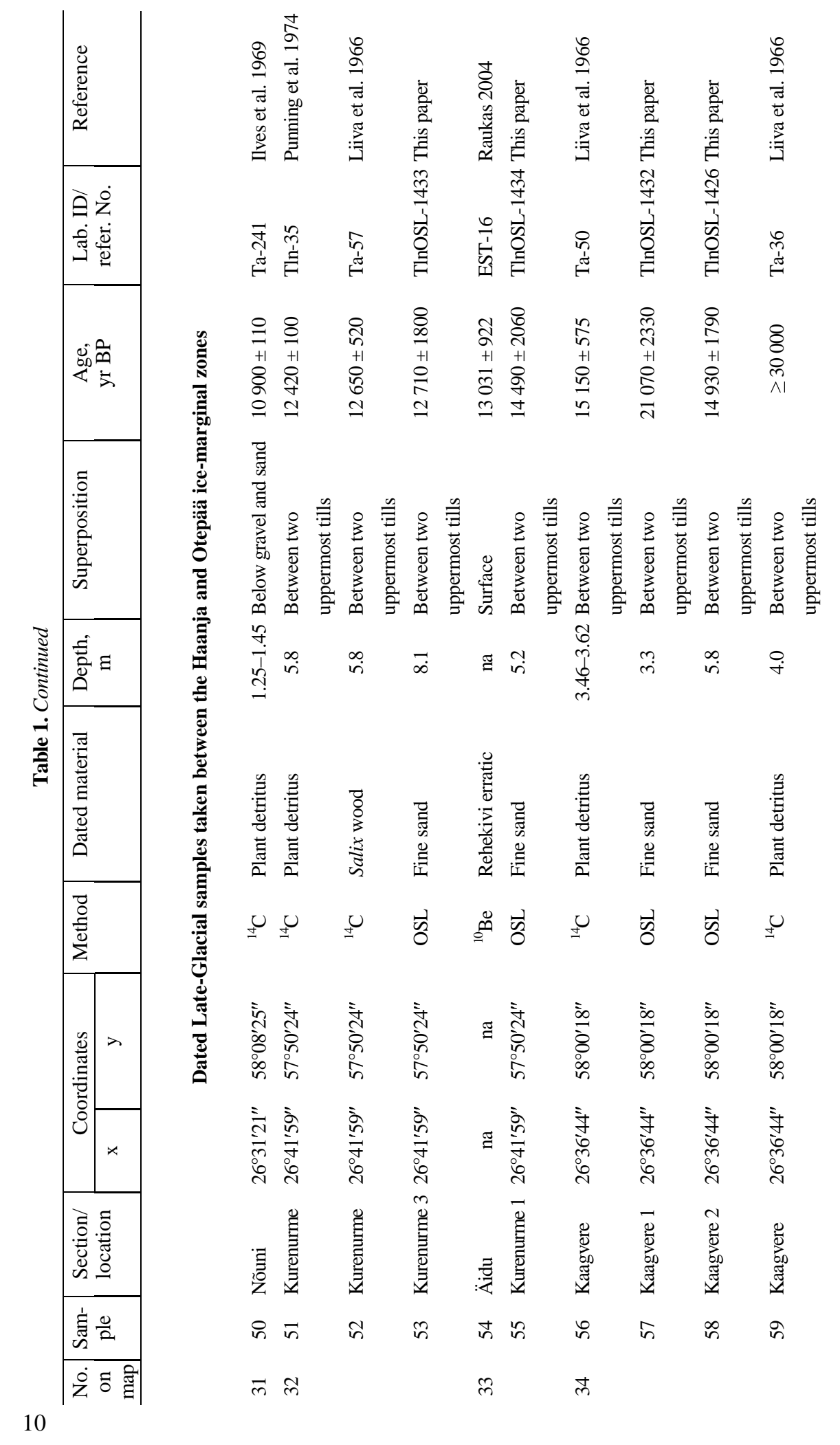




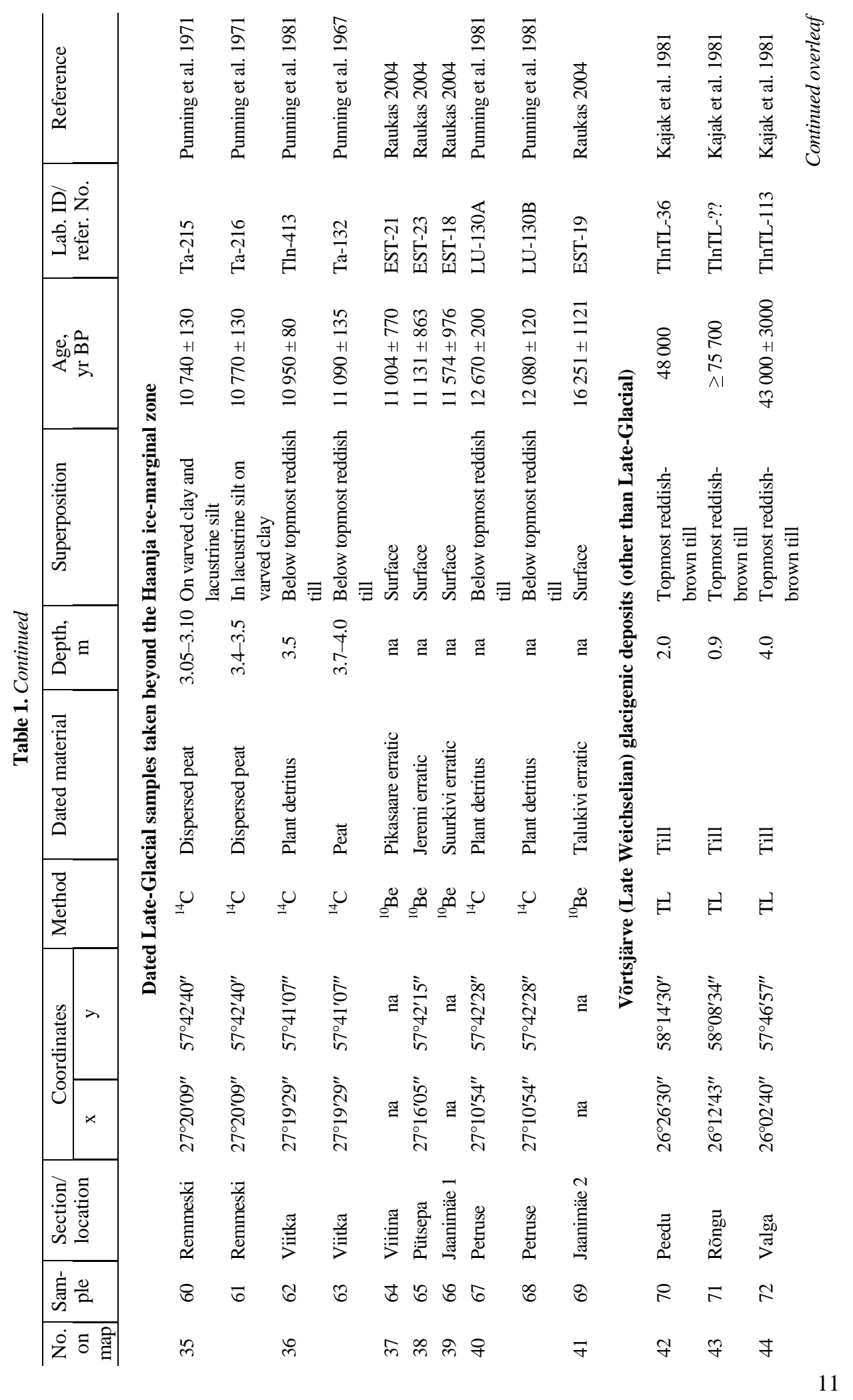




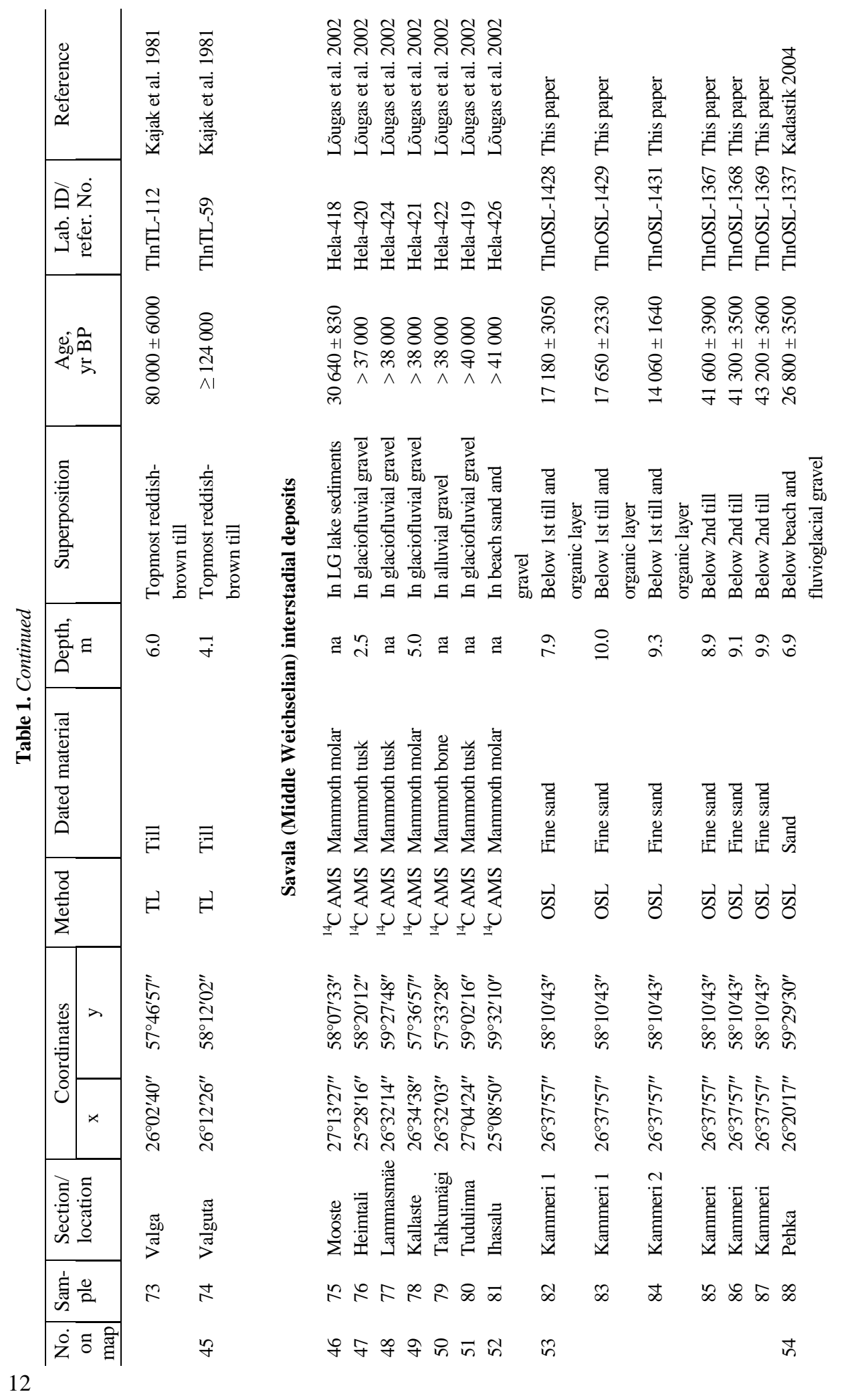




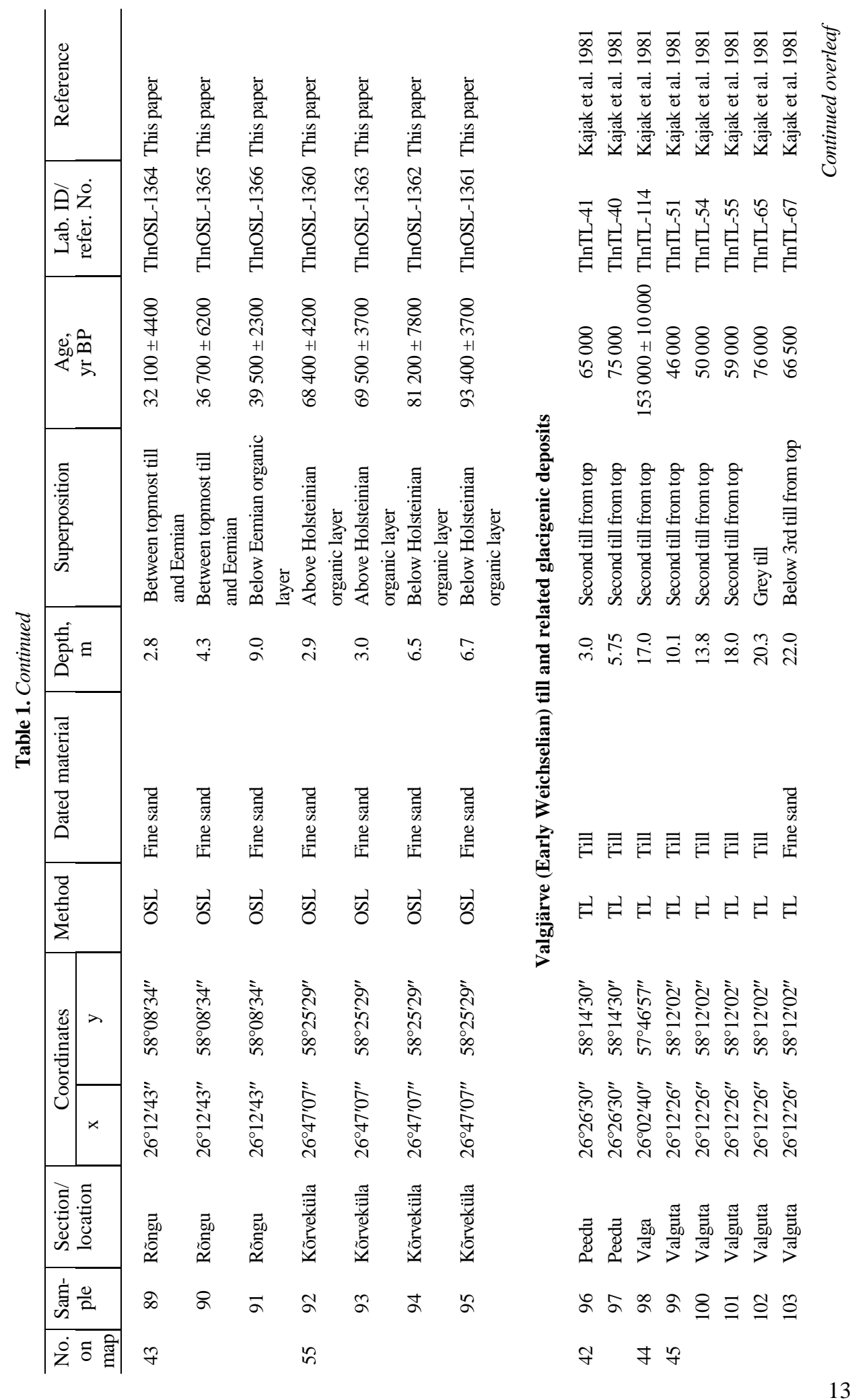




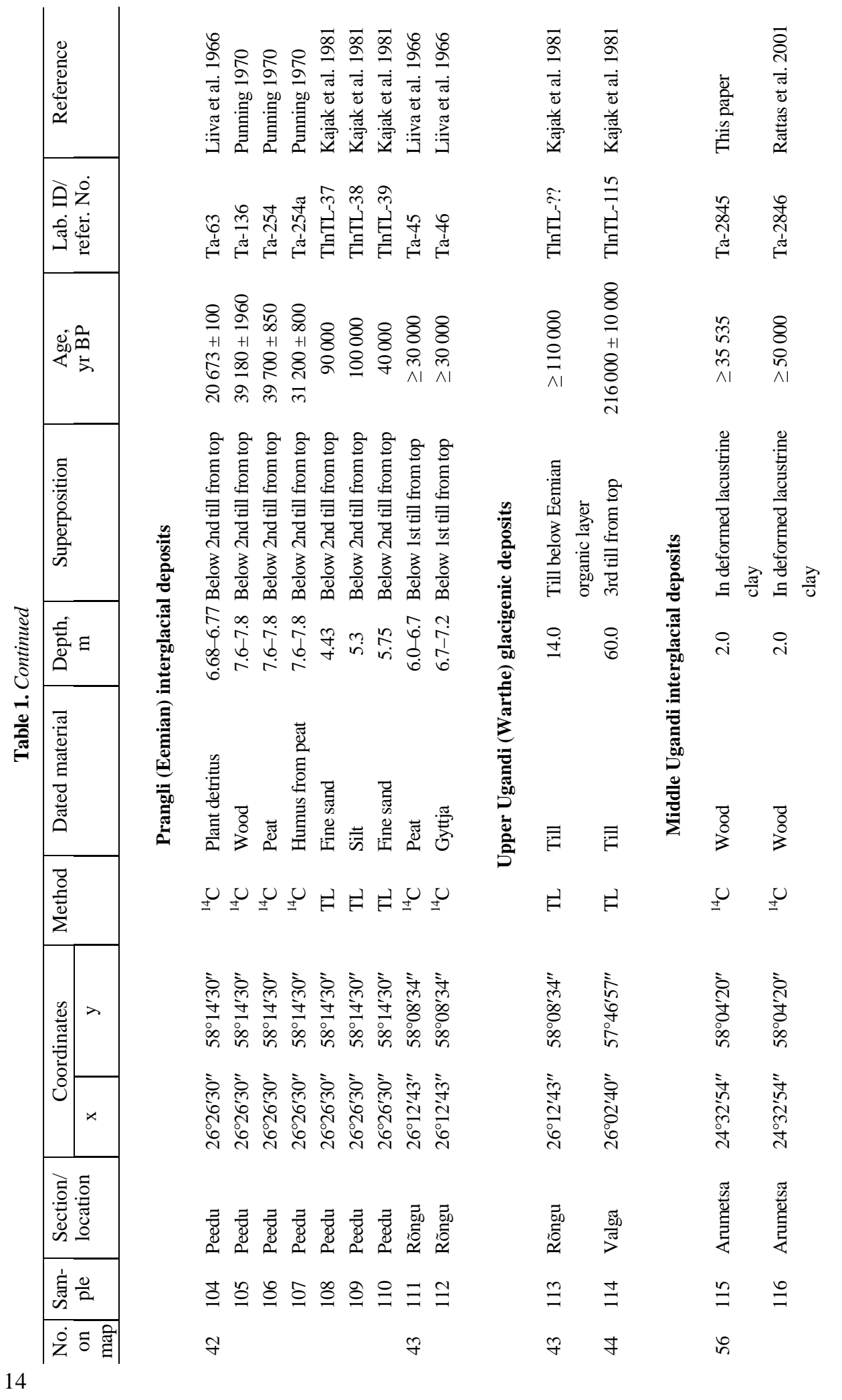




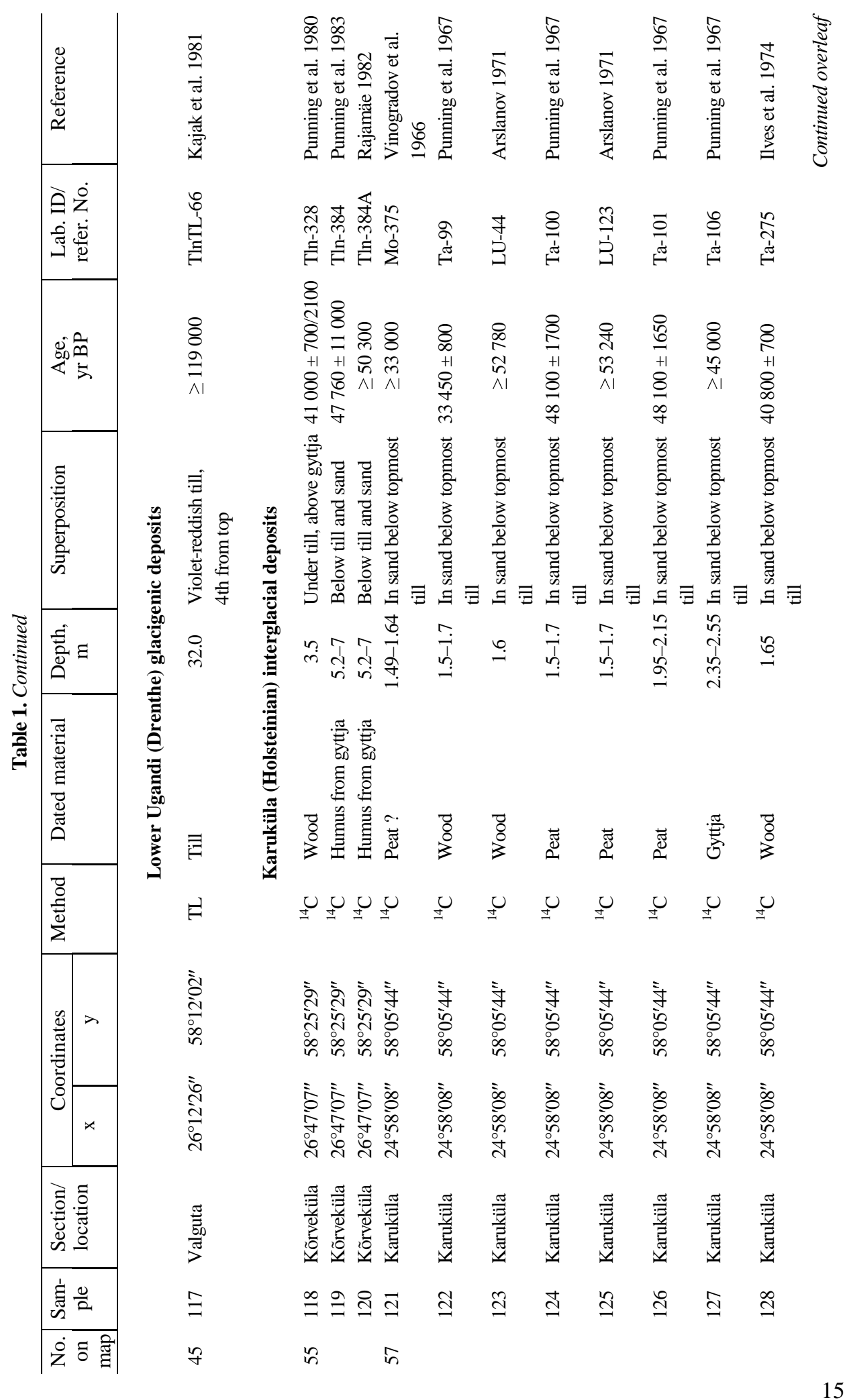




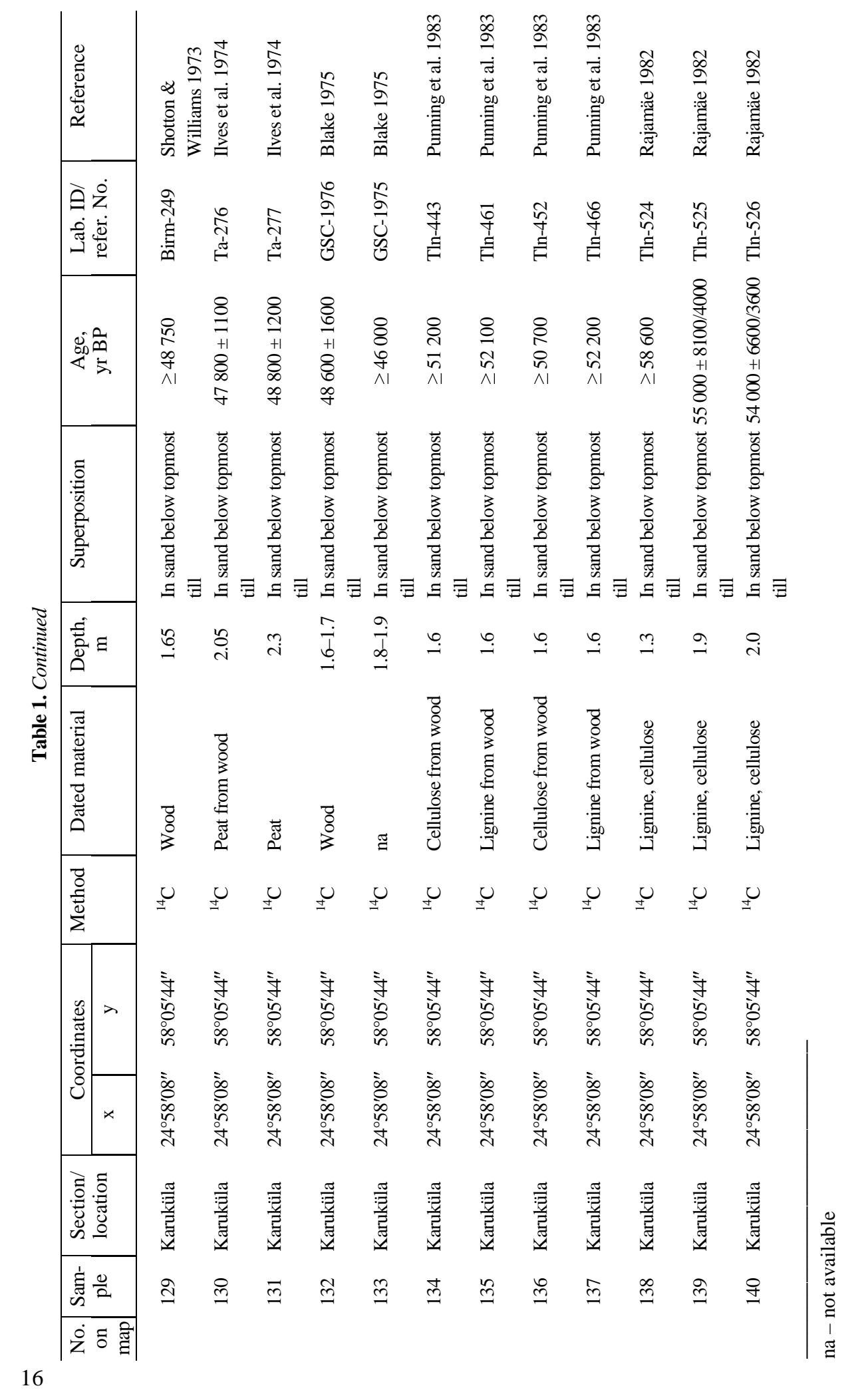


Sixty-nine out of the 140 dates are from Late-Glacial times and should refine the deglaciation chronology. The information on the dated material, sections, results, and references is summarized in Table 1. In a few cases some data (e.g. coordinates of a dated section, depth of sampling, laboratory index of dating) were not available to the author. Datings in Table 1 are presented in the increasing order, based on the age of the uppermost sample if more than one date exists per section, and grouped by zones of deglaciation or by stratigraphic units to which the dated samples have been assigned. The Estonian stratigraphic terminology (Raukas \& Kajak 1995; Pirrus \& Raukas 1996; Raukas et al. 2004) is used throughout the text. The ${ }^{14} \mathrm{C}$ ages are given in uncalibrated format.

\section{RADIOCARBON DATINGS}

The oldest dated sequences in Estonia are the two known Holsteinian organogenic deposits (lacustrine, bog) in the Karuküla and Kõrveküla sections (Fig. 1, Nos. 57 and 55, respectively). Since its discovery in 1939, the Karuküla section had been correlated with the Riss-Würm Interglacial (Orviku 1944, 1960), Brørup Interstadial (Orviku \& Pirrus 1965) or Middle Weichselian (Punning et al. 1969; Serebryannyj et al. 1969) interstadial or interglacial. The latest correlation was supported by $17{ }^{14} \mathrm{C}$ datings, most of which gave infinite ages (Table 1 ). The Holsteinian age of Karuküla deposits was first suggested by Danilans (1966). Later the Holsteinian age of the Karuküla and Kõrveküla sections was established by detailed palynological and carpological investigations (Velichkevich \& Liivrand 1976; Liivrand \& Saarse 1983; Liivrand 1984, 1991). Holsteinian pollen zones of the sections coincide fully and the biostratigraphic correlation with other known Holsteinian sections (Ulmale, Pulvernieki, Butenai, Likhvin) in northeastern Europe is certain (Velichkevich \& Liivrand 1976; Liivrand 1984, 1991; Kondratiene 1993). However, detailed coring has established that the interglacial deposits at both Holsteinian sites are allochthonous (Liivrand \& Saarse 1983; Levkov \& Liivrand 1988; Liivrand 1991). In the course of our recent study four new OSL dates for fine-grained fluvial sands from above (68 400 \pm 4200 and $69500 \pm 3700$ OSL yr BP) and below (81 200 \pm 7800 and $93400 \pm 3700$ OSL yr BP) the interglacial deposits of the Kõrveküla section were obtained. The OSL ages of the fluvial deposits confirm the allochthonous bedding of the interglacial gyttja with wood and peat. They do not confirm the Holsteinian age of the interglacial strata but do endorse the conclusion of palynological investigations on invalidity of altogether $23{ }^{14} \mathrm{C}$ dates from the Kõrveküla and Karuküla sections.

The history of dating the Prangli (Eemian) strata in Estonia is similar to that of Karuküla. Before the Eemian, the character of pollen assemblages zones was established in the Prangli, Rõngu, Peedu, and other sections (see Liivrand 1984, 1991). Six ${ }^{14} \mathrm{C}$ dates were determined, ranging between 20000 and $40000{ }^{14} \mathrm{C}$ yr BP 
(Table 1). The first dates referring to the Eemian age (90 000 and 100000 TL yr BP; Kajak et al. 1981) came from the alluvial sand and silt of the Peedu section (Fig. 1, No. 42) in southeastern Estonia. Recently the local stratotype section of the Eemian continental deposits at Rõngu (Fig. 1, No. 43) was re-examined and the fine laminated fluvial sand above and below the interglacial strata was dated using the OSL method. The dates obtained (32 100 4400 from above, and $36700 \pm 6200$ and $39500 \pm 2300$ OSL yr BP from below, Table 1) confirm the ages ( $\geq 30000{ }^{14} \mathrm{C}$ yr BP) of the earlier ${ }^{14} \mathrm{C}$ dates (Liiva et al. 1966) from the organic sediments. Nevertheless, palynological and diatom investigations have firmly established an Eemian age of the deposits in Rõngu and correlation to marine Eemian sections (Cheremisinova 1961; Liivrand 1984, 1991; Kondratiene 1993). Pollen diagrams compiled and interpreted by Liivrand $(1984,1991)$ show the entire interglacial cycle of vegetation development during this period. Similarly to Karuküla, most of the Prangli interglacial deposits in Estonia are found in glaciotectonically dislocated positions (Orviku 1939; Liivrand \& Saarse 1976; Liivrand 1991; Rattas \& Kalm 1999, 2004). Assuming that the conclusions from the pollen analysis and bedding conditions in the Rõngu section are valid, the OSL ages of the sands containing the erratics of Eemian layers designate glaciotectonic dislocations, which injected rafts of Eemian deposits into the Middle Weichselian sands. The seven oldest ${ }^{14} \mathrm{C}$ AMS dates of mammoth finds from Estonia published recently (Lõugas et al. 2002) cover a time span of 30600 to over $41000{ }^{14} \mathrm{C}$ yr BP (Table 1), suggesting the ice-free late Middle Weichselian in Estonia. However, most of the mammoth finds gave infinite ages and may be as old as Early Weichselian (Lõugas et al. 2002).

Since the beginning of research into the deglaciation history of Estonia, the Haanja Stade has always been considered the oldest Late Weichselian stadial on Estonian territory. The age of the Haanja Stade (ca $13400-13600{ }^{14} \mathrm{C}$ yr BP, Pirrus \& Raukas 1996) was determined from dating the Raunis intermorainic section (Dreimanis \& Zelčs 1995; Raukas 2004; Raukas et al. 2004; Zelčs \& Markots 2004) in northern Latvia. All measured Estonian ${ }^{14} \mathrm{C}$ dates from beyond the Haanja marginal belt (see Table 1) are restricted to superficial organogenic deposits (Remmeski, Fig. 1, No. 35) or to plant detritus and peat buried under till on slopes of hummocky relief (Viitka, No. 36; Petruse, No. 40). They are all younger than that from the Raunis section (Zelčs \& Markots 2004) and their interstadial nature is unclear. This feature may attest to a lengthy stagnant ice field on insular heights of glacial origin (Karukäpp \& Raukas 1994; Lundqvist \& Wohlfarth 2001), resultant slope- and thermokarst processes, and burial of organic sediments under colluvium. The ${ }^{14} \mathrm{C}$ dates obtained from those deposits do not indicate the age of possible ice advance, but instead may refer to the length of periglacial slope processes that were able to cover organic deposits under slumps and colluvium.

The distribution of ${ }^{14} \mathrm{C}$ ages against the chronostratigraphic scale (Fig. 2) shows a well-dated Late-Glacial, but also refers to ice-free late Middle Weichselian in Estonia. 


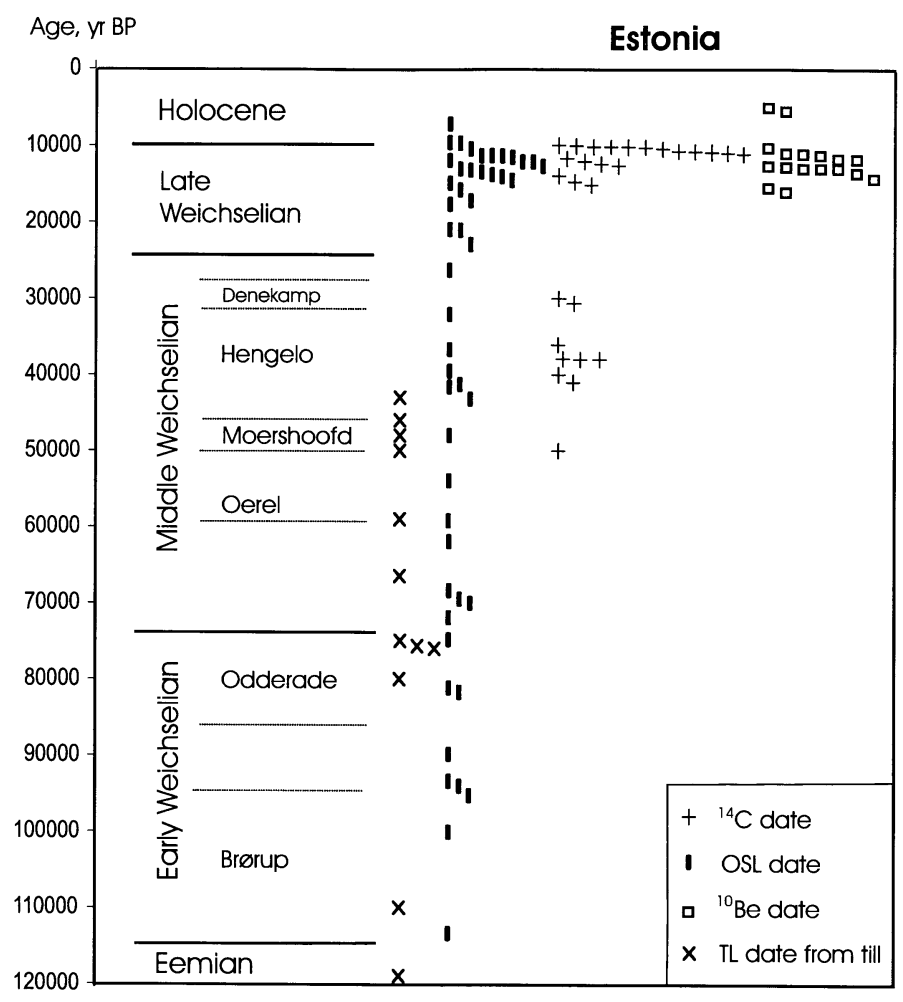

Fig. 2. Late Pleistocene datings from Estonia against the Late Pleistocene chronostratigraphy of Scandinavia (Donner 1995).

\section{LUMINESCENCE (TL, OSL) DATINGS}

Fifteen TL dates for different-aged tills in Estonia (Table 1) are available from the late 1970s (Kajak et al. 1981), the time of an over-optimistic approach to the developing TL method. Three of these dates are attributed to Ugandi (Saale) tills, the age of which originates from the superposition of the sampled layer (Kajak et al. 1981), i.e., the third (grey) or fourth (reddish-brown) till from the top, or under the Prangli (Eemian) interglacial sediments. Although the ages obtained are all older than 110000 TL years and may be considered Ugandian, the dating of tills itself, because of their highly variable genesis and problematic zeroing is very questionable (Punning \& Raukas 1983; Aitken 1985). Eight TL dates are available (Kajak et al. 1981) for the allegedly Valgjärve (Early Weichselian) purplishgrey till in southeastern Estonia (Raukas 1978; Kajak et al. 1981; Raukas \& Kajak 1995), which range between 153000 and $46000 \mathrm{yr}$ BP (Table 1). The TL method, arguably suitable for the dating of tills, gave the dates (the 153000 year 
age excluded) mostly reflecting Middle rather than Early Weichselian (Valgjärve) ages.

The new Early Weichselian (68 400-93 400 yr BP) OSL dates from the Kõrveküla section discussed earlier, together with $86000-105000 \mathrm{yr}$ EPR ages of Portlandia arctica shells from Latvia (Molodkov et al. 1998; Zelčs \& Markots 2004) suggest an ice-free Eastern Baltic during the Early Weichselian. Other new OSL dates of fine-grained laminated sands from the Pehka (Kadastik 2004; No. 54 in Fig. 1), Kammeri, and Rõngu sections (see Table 1) cover a time span of 26 800-43 200 OSL yr BP. Although the OSL dates range widely in different sections at the Kammeri site (Fig. 1, No. 53), the remaining ages show that Estonia was ice-free at least in the time span of 26 800-39 $500 \mathrm{yr}$ BP.

Recently a lengthy overview of the application of OSL and ${ }^{10} \mathrm{Be}$ methods to establishing deglaciation chronology for Estonia with a number of new datings was published (Raukas 2004). According to Raukas (2004), the errors of the OSL datings presented by him are often bigger than the duration of the whole deglaciation of the Estonian territory and the possibilities of the OSL method are highly overestimated. It may well be so. However, if we consider the OSL dates to refer solely to the time of the last natural bleaching of deposits, and do not assume that $100 \%$ of glacigenic sands and silts got bleached during the last deposition, we may easily explain, for example, the 59000 OSL yr date (Valgejõe) from the bottom of the Late-Glacial section of the glaciofluvial delta. More questionable are the early Holocene ages (Raukas 2004) of the topmost samples from the Palivere, Pannjärve, and Taimeaia sections. Nevertheless, the youngest Late-Glacial OSL dates from each of the sections presented by Raukas (2004) are mostly in a fair agreement with the early datings from the same deglaciation zones (Table 1). Only the error bars of the OSL datings are greater than that of ${ }^{14} \mathrm{C}$ and also ${ }^{10} \mathrm{Be}$ datings. Whatever the correctly estimated bleaching time (OSL age) was, it does refer to the time of sediment's occurrence in surficial conditions, probably in ice-free or periglacial situation. When plotting all available OSL dates, regardless of the expected age and superposition of dated layers, next to the Late Pleistocene chronostratigraphic scale (Fig. 2), we see (with the exception of the final 6000 years of the Late Weichselian) relatively even distribution of the dates in time. From this we derive a conclusion that there is no space for long-lasting ice-covers - glaciations of over 20000 years in duration - in Estonia during the Late Pleistocene.

\section{COSMOGENIC ${ }^{10}$ Be DATINGS}

The first ${ }^{10} \mathrm{Be}$ datings from Estonia became available very recently (Rinterknecht et al. 2003; Raukas 2004). The boulder exposure age method, discussed by Raukas (2004), is applicable in Estonia only in Late-Glacial chronology if glacial geology is concerned. Raukas (2004) provides $17{ }^{10} \mathrm{Be}$ dates obtained in collaborative research with P. Clark, V. Rinterknecht, and others. Rinterknecht et al. (2003) and 
Raukas (2004) dated the Palivere end moraine zone at $10000 \pm 1300{ }^{10} \mathrm{Be} \mathrm{yr} \mathrm{BP}$ (weighted mean age), one single boulder on the Pandivere end moraine at $13020 \pm 1117{ }^{10} \mathrm{Be}$ yr BP, and the Haanja (North Lithuanian) end moraine at $13000 \pm 800{ }^{10} \mathrm{Be} \mathrm{yr}$ (weighted mean age). Earlier Tschudi et al. (2000) have dated the younger Salpausselkä I zone end moraine at Lahti, southern Finland, at $11930 \pm 950$ or $12250 \pm 980$ (with or without consideration of erosion in ${ }^{10} \mathrm{Be}$ dating) years ago. Unexpectedly young ${ }^{10} \mathrm{Be}$ ages of the Palivere zone between the older Pandivere zone and younger Salpausselkä I zone are explained (Rinterknecht et al. 2003; Raukas 2004) by submergence of boulders by the Baltic Ice Lake and other local water-bodies, which substantially reduced the production rate of ${ }^{10} \mathrm{Be}$ for that period of time. The ${ }^{10} \mathrm{Be}$ ages provided for the Pandivere and Haanja end moraines differ from the presently used deglaciation age-model (Raukas 2004; Raukas et al. 2004) less than the inaccuracy of ${ }^{10} \mathrm{Be}$ datings. Thus the ${ }^{10} \mathrm{Be}$ method, because of relatively large uncertainty, does not contradict the earlier age estimations, nor can it refine the existing Late-Glacial chronology in Estonia.

\section{CONCLUSIONS}

Chronological data on Estonian Pleistocene are relatively abundant (140 available datings), but scattered. Half of the data cover only the youngest, 50006000 year part of the Late Weichselian. The almost even distribution of OSL datings against the Late Pleistocene chronostratigraphic scale, together with new ${ }^{14} \mathrm{C}$ AMS dates of mammoth finds (Lõugas et al. 2002) and EPR ages of Portlandia arctica shells from Latvia (Molodkov et al. 1998) leave no time-space for long-lasting (> ca 20000 years) glaciations in the Eastern Baltic during the last 100000 years.

Results of the ${ }^{10} \mathrm{Be}$ method (Rinterknecht et al. 2003; Raukas 2004), for the first time applied to the study of deglaciation chronology of Estonian territory, do not contradict the earlier age estimations. However, due to relatively large uncertainties of the method, the results were not able to refine the existing LateGlacial chronology in Estonia.

\section{ACKNOWLEDGEMENTS}

Kalju Kajak, Elsbet Liivrand, Leili Saarse, Tiit Hang, Maris Rattas, and Lembi Lõugas are acknowledged for discussions, consultancy during field works or for comments to the manuscript. Alar Rosentau and Mikk Ristna helped on the field. Dr. Robert Szava-Kovats is thanked for linguistic help. Special thanks go to Prof. Anto Raukas for his comments to the manuscript. Financial support of the Estonian Science Foundation (grant No. 5370) and Estonian State Target Foundation (project No. 0182530s03) are gratefully acknowledged. 


\section{REFERENCES}

Aitken, M. J. 1985. Thermoluminescence Dating. Academic Press, New York.

Arslanov, H. A. 1971. On the age of Karuküla deposits in southwestern Estonia. In Radiocarbon, pp. 205-215. Vilnius (in Russian).

Blake, W. (Jr.). 1975. Radiocarbon age determination from the Karuküla site, Southwestern Estonia, U.S.S.R. Report of Activities Geol. Survey of Canada, 1975, Paper 75-1, Part B, 123-127.

Cheremisinova, E. 1961. Diatoms of the marine interglacial deposits in the Estonian SSR. Dokl. Akad. Nauk SSSR, 141, 698-700 (in Russian).

Danilans, I. 1966. Pollen zones of Mindel-Riss deposits in the Letiža River basin and their comparison with similar zones of other regions. In Palynological Researches in the Baltic Soviet Republics (Bartosh, T., ed.), pp. 36-44. Zinatne, Riga (in Russian).

Donner, J. 1995. The Quaternary History of Scandinavia. World and Regional Geology, 7. Cambridge University Press.

Dreimanis, A. \& Zelčs, V. 1995. Pleistocene stratigraphy of Latvia. In Glacial Deposits in North-East Europe (Ehlers, J., Kozarski, S. \& Gibbard, Ph., eds.), pp. 105-113. Balkema, Rotterdam.

Harland, W., Cox, A., Llewellyn, P., Pickton, C., Smith, A. \& Walters, R. 1982. A Geologic Time Scale. Cambridge University Press, Cambridge.

Ilves, E., Punning, J.-M. \& Liiva, A. 1969. Verzeichnis der im Institut für Zoologie und Botanik der Akademie der Wissenschaften der Estnischen SSR mittels der Radiokohlenstoff-Methode datierten Proben. IV. Mitteilung. Eesti NSV Tead. Akad. Toim. Biol., 18, 417-426 (in Russian).

Ilves, E., Liiva, A. \& Punning, J.-M. 1974. Radiocarbon Dating in the Quaternary Geology and Archaeology of Estonia. Institute of Zoology and Botany, and Institute of Geology, Academy of Sciences of the Estonian S.S.R., Tallinn (in Russian).

Kadastik, E. 2004. Late-Weichselian stratigraphy and deglaciation palaeogeography in northwestern Estonia. Dissertationes Geologicae Universitatis Tartuensis, XV. Tartu University Press, Tartu.

Kajak, K., Kessel, H., Liivrand, E., Pirrus, R., Raukas, A. \& Sarv, A. 1976. Local stratigraphical scheme of Quaternary deposits in Estonia. In Stratigrafiya chetvertichnykh otlozhenij Pribaltiki (Vaitiekunas, P. P. \& Gaigalas, A. Y., eds.), pp. 4-52. Pergale, Vilnius (in Russian).

Kajak, K., Raukas, A. \& Hütt, G. 1981. Experience in dating different-aged tills of Estonia using thermoluminescence method. In Geologiya plejstotsena Severo-Zapada SSSR (Yevzerov, V. Ya., ed.), pp. 3-11. Kol'skij Filial AN SSSR, Apatity (in Russian).

Karukäpp, R. \& Raukas, A. 1994. Stagnant ice features in the eastern Baltic. Z. Geomorphologie, N.F., Suppl.-Bd., 95, 119-125.

Kessel, H. \& Punning, J.-M. 1969. Über die Verbreitung und Stratigraphie der Sedimente des Joldiameeres in Estland. Eesti NSV Tead. Akad. Toim. Keemia. Geol., 18, 154-163 (in Russian).

Kondratiene, O. 1993. Catalogue of Quaternary Stratotypes of the Baltic Region. Baltic Stratigraphical Association, Vilnius (in Russian).

Levkov, E. \& Liivrand, E. 1988. On glaciotectonical dislocations of interglacial deposits in Karuküla and Kõrveküla sections (Estonia). Proc. Acad. Sci. Estonian SSR Geol., 37, 161-167 (in Russian).

Liiva, A., Ilves, E. \& Punning, J.-M. 1966. Verzeichnis der im Institut für Zoologie und Botanik der Akademie der Wissenschaften der Estnischen SSR mittels der Radiokohlenstoff-Methode datierten Proben. Eesti NSV Tead. Akad. Toim. Biol., 15, 112-121 (in Russian).

Liivrand, E. 1984. The interglacials of Estonia. Ann. Acad. Sci. Fennicae, Ser. A, III Geol.-Geogr., 138.

Liivrand, E. 1991. Biostratigraphy of the Pleistocene Deposits in Estonia and Correlations in the Baltic Region. Department of Quaternary Research, Stockholm University. Report 19, Doctoral Thesis.

Liivrand, E. \& Saarse, L. 1976. Geological and palynological investigation of Upper Pleistocene intermorainic deposits at Peedu. Eesti NSV Tead. Akad. Toim. Keemia. Geol., 25, 334-342 (in Russian). 
Liivrand, E. \& Saarse, L. 1983. Interglacial deposits of the Kõrveküla section (South Estonia) and their stratigraphic importance. In Palynology in Geological Investigations in the Peribaltic Area and the Baltic Sea (Bartosh, T., ed.), pp. 41-59. Zinatne, Riga (in Russian).

Lõugas, L., Ukkonen, P. \& Jungner, H. 2002. Dating the extinction of European mammoths: new evidence from Estonia. Quat. Sci. Rev., 21, 1347-1354.

Lundqvist, J. \& Wohlfarth, B. 2001. Timing and east-west correlation of south Swedish ice marginal lines during the Late Weichselian. Quat. Sci. Rev., 20, 1127-1148.

Molodkov, A., Dreimanis, A., Āboltinš, O. \& Raukas, A. 1998. The age of Portlania arctica shells from glacial deposits of Central Latvia: an answer to a controversy on the age and genesis of their enclosing sediments. Quat. Geochronol., 17, 1077-1094.

Moora, T. 1998. Muistsete loodusolude osast kiviaja asustuse kujunemisel Kunda ümbruses. In Muinasaja teadus 5, Loodus, inimene ja tehnoloogia. Interdistsiplinaarseid uurimusi arheoloogias, pp. 15-151. Ajaloo Instituut, Tallinn.

Moora, T., Raukas, A. \& Tavast, E. 2002. Geological history of Lake Võrtsjärv. Proc. Estonian Acad. Sci. Geol., 51, 157-179.

Orviku, K. 1939. Rõngu interglatsiaal - esimene interglatsiaalse vanusega setete leid Eestist. Eesti Loodus, 1, 1-21.

Orviku, K. 1944. Jääaegade geoloogiast Eestis. Eesti Sõna, 138, p. 4.

Orviku, K. K. 1960. Quaternary System (Anthropogenic deposits)]. In Geologiya SSSR. Éstonskaya SSR, Vol. 28 (Orviku, K. K., Kotlukov, V. A. \& Müürisepp, K. K., eds.), pp. 166-194. Gosgeoltehizdat, Moscow (in Russian).

Orviku, K. K. \& Pirrus, R. O. 1965. Intermorainic organogenic deposits of Karuküla (Estonian SSR). In Litologiya i stratigrafiya chetvertichnykh otlozhenij Éstonii (Orviku, K. K., ed.), pp. 3-20. Institut geologii, Akad. Nauk ÉSSR, Tallinn (in Russian).

Pirrus, R. \& Raukas, A. 1996. Late-Glacial stratigraphy in Estonia. Proc. Estonian Acad. Sci. Geol., 45, 34-35.

Punning, J.-M. 1970. On possible errors in the determination of sample age by means of radioactive carbon $\left(\mathrm{C}^{14}\right)$ and on the checking of results. Eesti NSV Tead. Akad. Toim. Keemia. Geol., 19, 238-243 (in Russian).

Punning, J.-M., Ilves, E. \& Liiva, A. 1967. Verzeichnis der im Institut für Zoologie und Botanik der Akademie der Wissenschaften der Estnischen SSR mittels der Radiokohlenstoff-Methode datierten Proben. II. Mitteilung. Eesti NSV Tead. Akad. Toim. Biol., 16, $408-414$ (in Russian).

Punning, J.-M., Liiva, A. \& Ilves, E. 1968. Verzeichnis der im Institut für Zoologie und Botanik der Akademie der Wissenschaften der Estnischen SSR mittels der Radiokohlenstoff-Methode datierten Proben. III. Mitteilung. Eesti NSV Tead. Akad. Toim. Biol., 17, 426-430 (in Russian).

Punning, J.-M., Raukas, A. \& Serebryannyj, L. 1969. Karuküla interglacial deposits in the Russian Plain (stratigraphy and geochronology). Izv. Akad. Nauk SSSR, Geol., 10, 148-151 (in Russian).

Punning, J.-M., Ilves, E., Liiva, A. \& Rinne, T. 1971. Verzeichnis der im Institut für Zoologie und Botanik der Akademie der Wissenschaften der Estnischen SSR mittels der RadiokohlenstoffMethode datierten Proben. V. Mitteilung. Eesti NSV Tead. Akad. Toim. Biol., 20, 174-178 (in Russian).

Punning, J.-M., Kakum, T. \& Rajamäe, R. 1974. List of samples dated by the radiocarbon method at the Institute of Geology of the Academy of Sciences of the Estonian SSR. Eesti NSV Tead. Akad. Toim. Keemia. Geol., 1, 65-71 (in Russian).

Punning, J.-M., Rajamäe, R., Jõers, K. \& Putnik, H. 1980. List of samples dated by the radiocarbon method at the Institute of Geology of the Academy of Sciences of the Estonian SSR. V-VI. Eesti NSV Tead. Akad. Toim. Geol., 29, 34-47 (in Russian).

Punning, J.-M., Raukas, A. \& Rajamäe, R. 1981. On dynamics of the second Late-Pleistocene Glaciation in the Northern Hemisphere. In Glacial Deposits and Glacial History in Eastern Fennoscandia (Gorbunov, G. I., Koshechkin, B. I. \& Lisitsyn, A. I., eds.), pp. 80-89. Kola Branch of the USSR Academy of Sciences, Apatity. 
Punning, J.-M., Rajamäe, R., Jõers, K. \& Putnik, H. 1983. Spisok radiouglerodnykh datirovok Instituta geologii AN ÉSSR, VIII. Tallinn (in Russian).

Punning, J.-M. \& Raukas, A. 1983. The age of tills: problems and methods. In Tills and Related Deposits. Genesis, Petrology, Application, Stratigraphy (Evenson, E., Schlüchter, Ch. \& Rabassa, J., eds.), pp. 357-364. Balkema, Rotterdam.

Rajamäe, R. 1982. Geokhronologiya pozdnego plejstotsena severo-zapadnoj chasti VostochnoEvropejskoj ravniny po dannym usovershenstvovannogo radiouglerodnogo metoda. Abstract of doctoral thesis. Institut geologii, Akad. Nauk ÉSSR, Tallinn (in Russian).

Rattas, M. \& Kalm, V. 1999. Classification and areal distribution of glaciotectonic features in Estonia. Geol. Quarterly, 43, 177-182.

Rattas, M. \& Kalm, V. 2004. Glaciotectonic deformation patterns in Estonia. Geol. Quarterly, 48, $15-22$.

Rattas, M., Kirsimäe, K., Ainsaar, L., Meidla, T., Sakson, M. \& Tinn, O. 2001. Arumetsa clay deposit and quarry. In Excursion Guide of the Balteem Workshop, March 30-April 2, 2001. Lepanina, Estonia. Institute of Geology, University of Tartu, Tartu.

Raukas, A. 1978. Pleistocene Deposits of the Estonian SSR. Valgus, Tallinn (in Russian).

Raukas, A. 1998. Outlines of the Estonian Quaternary stratigraphy. In Relief and Deposits of Present-day and Pleistocene Glaciation of the Northern Hemisphere, Selected Problems (Kostrzewski, A., ed.). Adam Mickiewicz Univ. Poznan. Geogr. Ser., 58, 215-234.

Raukas, A. 2004. Application of OSL and ${ }^{10} \mathrm{Be}$ techniques to the establishment of deglaciation chronology in Estonia. Proc. Estonian Acad. Sci. Geol., 53, 267-287.

Raukas, A. \& Gaigalas, A. 1993. Pleistocene glacial deposits along the eastern periphery of the Scandinavian ice sheets - an overview. Boreas, 22, 214-222.

Raukas, A. \& Kajak, K. 1995. Quaternary stratigraphy in Estonia. Proc. Estonian Acad. Sci. Geol., 44, 149-162.

Raukas, A. \& Kajak, K. 1997. Quaternary cover. In Geology and Mineral Resources of Estonia (Raukas, A. \& Teedumäe, A., eds.), pp. 125-136. Estonian Academy Publishers, Tallinn.

Raukas, A., Kalm, V., Karukäpp, R. \& Rattas, M. 2004. Pleistocene glaciations in Estonia. In Quaternary Glaciations-Extent and Chronology, Part I: Europe (Ehlers, J. \& Gibbard, P. L., eds.), pp. 83-91. Elsevier, Amsterdam.

Rinterknecht, V. R., Raisbeck, G. R., Yiou, F., Clark, P. U., Brook, E. Y., Bitinas, A., Lunkka, J., Marks, L., Pavlovskaya, I. \& Piotrowski, J. 2003. ${ }^{10}$ Be deglaciation chronology of the southern margin of the Scandinavian ice sheet. In XVI INQUA Congress. Programs with Abstracts. Reno, Nevada, USA, 83/10.

Sarv, A. \& Ilves, E. 1975. Über das alter der Holozänen Ablagerungen im Mündungsgebiet des Flusses Emajõgi (Saviku). Eesti NSV Tead. Akad. Toim. Keemia. Geol., 24, 64-69 (in Russian).

Serebryannyj, L. R. \& Raukas, A. V. 1966. Trans-Baltic correlations of ice-marginal formations of Late Pleistocene. In Verkhnij plejstotsen. Stratigrafiya i absolyutnaya geokhronologiya (Grichuk, V. P., Ivanova, I. K., Kind, N. V. \& Ravskij, E. Y., eds.), pp. 12-28. Nauka, Moscow (in Russian).

Serebryannyj, L. R., Raukas, A. V. \& Punning, J.-M. K. 1969. On the history of the development of glaciation in the northwestern part of the Russian Plain in the Late Pleistocene. Materialy glyatsiol. issledovanij. Khronika. Obsuzhdeniya, 15, 167-181 (in Russian).

Shotton, F. W. \& Williams, R. E. 1973. Birmingham University radiocarbon dates VI. Radiocarbon, 15, 1-12.

Tschudi, S., Ivy-Ochs, S., Schlüchter, C., Kubik, P. \& Rainio, H. 2000. ${ }^{10}$ Be dating of Younger Dryas Salpausselkä I formation in Finland. Boreas, 29, 287-293.

Ukkonen, P., Lõugas, L., Zagorska, I., Lukševiča, L., Lukševičs, E., Daugnora, L. \& Jungner, H. 2005. Recolonization and local extinction of the glacial reindeer (Rangifer tarandus L.) in the Baltic region after the Weichselian maximum. Boreas (submitted). 
Velichkevich, F. \& Liivrand, E. 1976. New investigations of the interglacial flora from Karuküla section in Estonia. Eesti NSV Tead. Akad. Toim. Keemia. Geol., 25, 215-221 (in Russian).

Vinogradov, A. P., Devirts, A. L., Dobkina, E. I. \& Markova, N. G. 1966. Data from the radiocarbon laboratory of the V. I. Vernadski Institute of Geochemistry and Analytical Chemistry of the Academy of Sciences, USSR. In Verkhnij plejstotsen. Stratigrafiya i absolyutnaya geokhronologiya (Grichuk, V. P., Ivanova, I. K., Kind, N. V. \& Ravskij, E. Y., eds.), pp. 240249. Nauka, Moscow (in Russian).

Zelčs, V. \& Markots, A. 2004. Deglaciation history of Latvia. In Quaternary Glaciations-Extent and Chronology, Part I: Europe (Ehlers, J. \& Gibbard, P. L., eds.), pp. 225-243. Elsevier, Amsterdam.

\section{Eesti Pleistotseeni kronoloogiline andmestik}

\section{Volli Kalm}

Eesti Pleistotseeni kronostratigraafia põhineb käesoleval hetkel 60 radiosüsiniku$\left({ }^{14} \mathrm{C}\right.$ ja ${ }^{14} \mathrm{C}$ AMS $), 63$ TL- või OSL- ja $17{ }^{10} \mathrm{Be}$-meetodiga tehtud vanusemäärangul, kokku 57 erinevast läbilõikest või objektist. Ajaliselt katavad dateeringud ligikaudu 200000 aastat Pleistotseeni noorimast osast. Artiklis on esmakordselt kokku võetud ja süstematiseeritud 40-aastase geokronoloogilise uurimistöö kõik kättesaadavad faktilised andmed ning neid kriitiliselt hinnatud. Pooled 140 dateeringust langevad Pleistotseeni noorimasse, 5000-6000 aasta pikkusesse intervalli, iseloomustades eelkõige hilisglatsiaali. Uusimad OSL-dateeringud koos varasemate palünoloogiliste ja karpoloogiliste uuringute tulemustega lubavad väita, et ligikaudu kolmandikku 1960. ja 1970. aastatel tehtud ${ }^{14} \mathrm{C}$-dateeringutest ei saa usaldada põhjusel, et dateeritava materjali tegelik vanus ületas meetodi määramispiiri. Samuti on 1980. aastatel moreenist saadud TL-vanused ebausaldusväärsed TL-signaali "nullistumise" problemaatilisuse tõttu. ${ }^{10} \mathrm{Be}$-meetodi tulemused Balti jääpaisjärve veetasemest kõrgemale jäävate hilisglatsiaali servamoodustiste dateerimisel ei läinud konflikti varasemate vanusemäärangutega, kuid suhteliselt suure määramisvea tõttu ei võimaldanud neid ka täpsustada. 